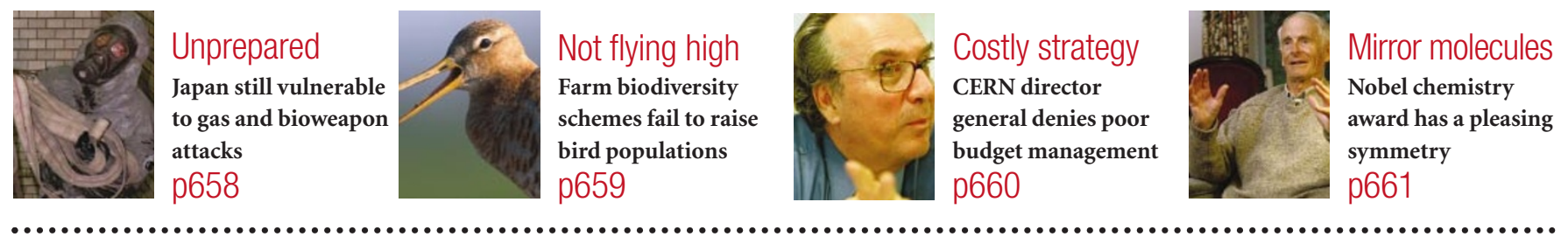

\title{
Genetic sleuths rush to identify anthrax strains in mail attacks
}

\section{Rex Dalton, San Diego}

As reports of anthrax attacks across the United States multiplied earlier this week, researchers scrambled to identify the strains of bacteria involved. Such information will be vital in shaping the investigation of the attacks, and the political response to them.

Investigators hope that new analytical approaches will shed light on the origins of anthrax spores sent through the mail. As Nature went to press, envelopes containing spores had already been confirmed in Florida, New York, Nevada and at the offices of majority senate leader Tom Daschle (Democrat, South Dakota) in Washington. If they all involve the same strain, for example, it would indicate that they are part of a coordinated attack.

As the number of reported attacks rose over the weekend, health secretary Tommy Thompson said that the White House would ask Congress for an additional \$1.5 billion to counter bioterrorism and purchase antibiotics.

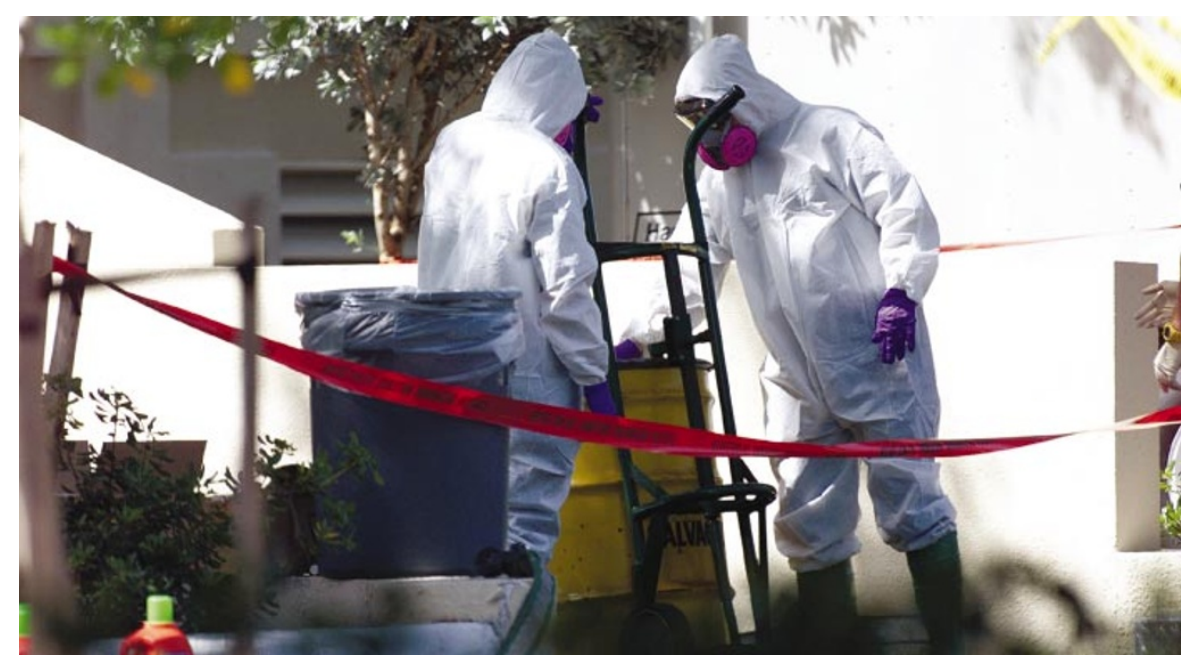

Handled with care: FBI agents remove suspicious material from newspaper offices in Florida.

According to sources close to the investigation, the laboratory of Paul Keim, a geneticist at the Northern Arizona University (NAU) in Flagstaff, has taken an early lead in identifying

\section{Bioweapons treaty under threat}

\section{Declan Butler, Paris}

Even as envelopes containing anthrax spores are increasing fears of bioterrorism in the United States, a flashpoint looms for the international treaty intended to help prevent such attacks.

A lack of consensus over verification threatens to unravel the 1972 Biological Weapons Convention (BWC) at a meeting next month.

Years of efforts to give the BWC teeth collapsed in July, when the United States vetoed a proposed verification protocol for the treaty (see Nature 412, 365; 2001).

US officials last week confirmed that the 11 September attacks had not shifted their position. Avis Bohlen, assistant secretary of state for arms control, told a United Nations forum that the events had "reinforced our view" that verification was unworkable.

More detailed proposals of verification measures were put forward in Paris last week by US officials at a closed meeting of the Australia Group, an informal alliance of 33 countries that aims to limit the proliferation of dangerous agents and technologies through export controls. But other delegates were unconvinced that the United States can suggest a meaningful alternative to the protocol it rejected in July.

The next of the BWC's five-yearly review meetings is scheduled for next month, and the treaty requires all participants to reach a consensus, however bland, at such meetings. Officials fear that some parties, such as Iran or Cuba, may attack the US verification veto, causing a complete breakdown in the process.

"If you don't get consensus, then you don't have another conference in five years' time, and then the BWC is dead," says Julian Perry Robinson, a disarmament expert at the University of Sussex, UK. the strains of the causative bacterium, Bacillus anthracis, involved in the attacks.

The authorities turned to Keim's lab immediately after the Florida attacks because of its published record of describing anthrax strains and its role in developing analytical techniques to identify the strains.

In 1998, Keim's team played a key role in proving that a deadly outbreak of anthrax at Sverdlovsk in Russia involved multiple strains of the bacterium, and so was related to an escape of material from germ-warfare facilities and not a natural outbreak, as Russia had claimed (P. J. Jackson et al. Proc. Natl Acad. Sci. USA 95, 1224-1229; 1998).

Although Keim declined to discuss specifics of the latest investigation or the results of his tests, authorities have said the anthrax spores in the Florida attack are believed to be a derivative of the virulent 'Ames strain'. This was commonly used in laboratories for research, developing vaccines and tests, after its original isolate was removed from a dead animal in the 1950s near Ames, Iowa.

More than 1,200 strains of $B$. anthracis have been identified around the world over the years, and the NAU laboratory has used AFLP (amplified fragment length polymorphism) DNA analysis to examine all of them.

This technique uses enzymes to cut the 
bacterium's genome into random fragments, and then uses the polymerase chain reaction (PCR) to amplify some of the fragments. Sequence variation between strains, and variation in the length of regions in which small stretches of sequence are repeated, results in a different pattern of amplified fragments for each strain. Data derived from the AFLP

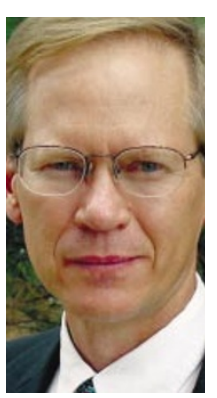
technique are held on databases at the NAU and at the Los Alamos National Laboratory in New Mexico.

But Keim's lab has also adapted a more precise test called multilocus VNTR (variablenumber tandem repeat) analysis, or MLVA, for Taking the strain: use with microorganPaul Keim. isms. With MLVA, researchers use PCR to amplify regions of the genome containing repeated sequences and so develop a genetic fingerprint for a strain or species. MLVA has so far been performed on about 400 of the 1,200 known strains of B. anthracis.

The genome of $B$. anthracis contains short sequences of DNA that, depending on the strain, are repeated a different number of times at certain loci. Keim's group has published findings on eight such markers used to probe these loci, using a technique that is similar to that used in genetic fingerprinting for paternity suits or criminal investigations. Keim's team has a total of about $50 \mathrm{~B}$. anthracis markers at its disposal, and is working on more markers for the roughly 1,000 VNTR loci in the bacterium's genome. "This is a highly precise method that also can be used for tuberculosis, Escherichia coli and other pathogens," says Keim.

It takes about 12 hours for Keim's lab to analyse an anthrax sample. Once a strain is identified, investigators can try to match it to its original source - but this is not always easy. The Ames strain, for example, has been passed around the world by researchers - the sample held by the NAU came from Britain's chemical and biological defence facility at Porton Down, which received it from the US Army Medical Research Institute of Infectious Diseases at Fort Detrick in Maryland.

In the future, analysis of anthrax will get a boost from the sequencing of a derivative of the Ames strain by The Institute for Genomic Research (TIGR) in Maryland. Timothy Read, a bacterial genomicist at TIGR, says he expects to close the final gaps in the strain's sequence in the next few months. Other strains will also be sequenced in the near future.

http://herb.bio.nau.edu/ genetics/project3.htm

\section{Scientific leaders respond to US government's call to arms}

\section{Jonathan Knight, San Francisco}

Leaders of the US scientific community are developing plans to work closely with government agencies and the military in the fight against terrorism.

On 26 September, for example, Bruce Alberts, president of the National Academy of Sciences, convened a meeting of 30 prominent scientists and security experts to discuss the role of science in the aftermath of the 11 September attacks on New York and Washington.

Those attending included Norman Augustine, chairman of aeronautics company Lockheed Martin; John Marburger, director of the Department of Energy's Brookhaven National Laboratory and President George W. Bush's nominated science adviser; Wolfgang Panofsky, a director of the Stanford Linear Accelerator Center; former senator Sam Nunn; and James Woolsey, former head of the Central Intelligence Agency.

"All were clearly concerned that the scientific and technical community hasn't played an important role in the issue of dealing with organized terrorism," says Kumar Patel, a former president of the American Physical Society, who also attended the meeting.
Several federal agencies, including the National Science Foundation and the Defense Advanced Research Projects Agency, currently fund counter-terrorism research. But according Maxine Singer, president of the Carnegie Institution, who was present at the meeting, they sometimes fail to draw on the full creative potential of the academic community. "Things have become institutionalized," she says.

Both the White House Office of Science and Technology Policy and the Pentagon's Technical Support Working Group have approached the academy complex to ask for input, says Bill Colglazier, executive director of the National Research Council. "They want cutting-edge people to help with brainstorming and advising," he says.

To coordinate this input, the academies are planning to spend $\$ 500,000$ of their own money to help create a task force with an anti-terrorist research agenda, called the Multi-Agency Program Plan for Science and Technology. Lewis Branscomb, a technology-policy specialist at Harvard University, and Richard Klausner, a former director of the National Cancer Institute, are leading the project.

\section{Gaps remain in Japan's biodefences}

\section{David Cyranoski, Tokyo}

Japan remains vulnerable to bioterrorist and chemical attacks, citizen groups and biomedical researchers are warning. Despite

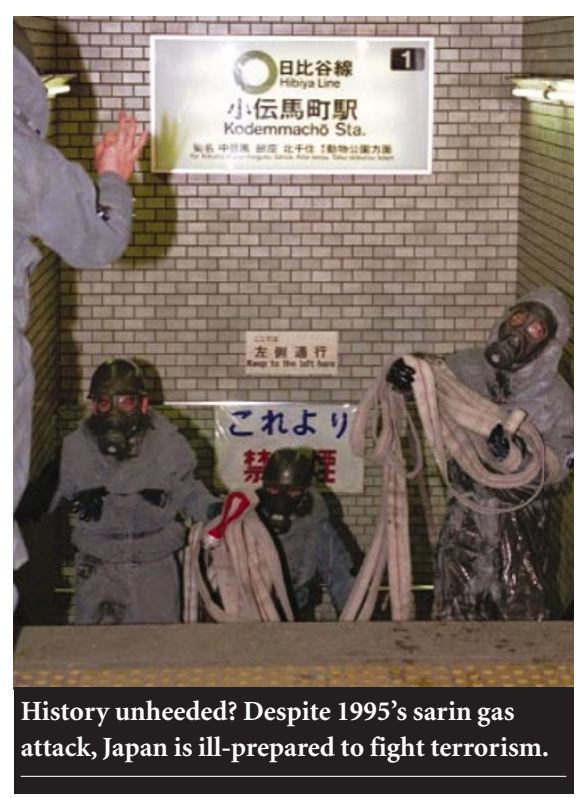

suffering the 1995 sarin nerve-gas attack on the Tokyo subway, the government has not taken sufficient action, the groups say.

"Now many hospitals and clinics are aware of emergency measures for sarin treatment," says Masanori Fukushima, an epidemiologist at Kyoto University, "but there is no preparation for recognizing victims of bioterrorism."

Yukitatsu Kawamoto, of the Citizen's Centre for the Prevention of Biohazards in Chiba, notes that in 1993 Aum Shinrikyo, the cult behind the sarin attack, sprayed a non-virulent strain of anthrax from the roof of its Tokyo headquarters. "The authorities never tracked down where Aum got it, and they haven't taken measures to account for such materials since then," he says.

And last week Yasuo Fukuda, the government's chief cabinet secretary, admitted that Japan's anti-terrorism preparations are inadequate.

But Toshinobu Sato, director of the Office of Health Crisis Management, claims that security at health-ministry institutes is sufficient to prevent anyone from removing potential biological weapons. 